\title{
MATHEMATICAL MODELING AND HYSTERESIS OF SORPTION ISOTHERMS FOR PADDY RICE GRAINS
}

\author{
Juliana S. Zeymer ${ }^{*}$, Paulo C. Corrêa ${ }^{2}$, Gabriel H. H. Oliveira ${ }^{3}$, Fernanda M. Baptestini ${ }^{4}$, \\ Renata C. Campos ${ }^{2}$
}

${ }^{1 *}$ Corresponding author. Federal University of Viçosa/ Viçosa - MG, Brazil.

E-mail: jujuszeymer@gmail.com | ORCID ID: http://orcid.org/0000-0003-1553-3494

\section{KEYWORDS}

adsorption, desorption, hygroscopic equilibrium, relative humidity, temperature.

\begin{abstract}
Knowledge on sorption isotherms is important for predicting drying and storage processes of a product. A sorption isotherm can be generated from two processes: desorption and adsorption. The lag between these two curves is called hysteresis. Static method was used to obtain the equilibrium moisture content of paddy rice grains, in different temperature (10, $20,30,40$ and $50 \pm 1{ }^{\circ} \mathrm{C}$ ) and relative humidity (between 11 and $76 \% \pm 2 \%$ ) conditions. Equilibrium moisture content data were correlated with eight mathematical models and. The Chung Pfost model had the best fit to the experimental data. Desorption and adsorption isotherms, represented by the Chung Pfost model, showed a sigmoidal shape, characteristic of type II curve. Equilibrium moisture content values obtained by desorption were higher than those obtained by adsorption, evidencing the hysteresis phenomenon.
\end{abstract}

\section{INTRODUCTION}

Rice (Oryza sativa L.) is a cereal of elevated economic and social value, being a basic food for more than half of the world's population (Utami et al., 2017). It is one of the three most produced and consumed cereals worldwide, behind wheat and corn (Ziegler et al., 2017).

Rice is harvested according to the seasons over the year, and post-harvest procedures are determinant for rice quality maintenance throughout the year (Ziegler et al., 2017). A series of physical-chemical, biochemical and metabolic reactions happen during rice grain storage. These reactions are directly influenced by the storage system, initial grain quality, grain moisture content, temperature and air relative humidity in the storage environment (Chen et al., 2015).

Equilibrium moisture content is given by the equilibrium between moisture content of the grains, and the psychrometric conditions of the surrounding air. This condition is reached when the partial pressure of water vapor in the product is equal to the partial pressure of water vapor in the surrounding air (Corrêa et al., 2014). Equilibrium moisture content is useful for determining water loss or gain under certain conditions of temperature and relative humidity, and is directly related to drying, aeration and storage (Corrêa et al., 2010).
For constant air relative humidity and water activity, there are two equilibrium moisture contents, depending on the experimental conditions (adsorption or desorption), since the product may have a lower or higher moisture content than the equilibrium for the current environmental conditions (Corrêa et al., 2014). For a given water activity, the equilibrium moisture content values, in a given water activity, is higher in desorption isotherm than in adsorption isotherm.

According to Brooker et al. (1992), this phenomenon occurs because grains are porous materials formed by narrow capillaries of small diameters and tubes of bigger diameters. In addition to that, pores of small diameters control capillary emptying during the desorption process, resulting in the reduction of relative humidity in the grain porous media. When grain gains moisture during adsorption process, capillaries are not completely filled as they were prior to desorption, leading to a lower moisture content value than before, which is the hysteresis effect (Wolf et al., 1972). Hysteresis is important to determine the required protection against moisture gain and to estimate deterioration possibility due to chemical reactions and microorganisms (Fellows, 2006).

\footnotetext{
${ }^{2}$ Federal University of Viçosa/ Viçosa - MG, Brazil.

${ }^{3}$ Federal Institute of Minas Gerais Southeast/ Manhuaçu - MG, Brazil.

${ }^{4}$ Federal University of Espírito Santo/ Alegre - ES, Brazil.

Received in: 5-2-2018

Accepted in: 6-10-2019
} 
Relationship between a product's moisture content and relative humidity at equilibrium (water activity) may be expressed by mathematical models. These models are important, because they report the product's moisture content at a given environmental condition, without the need to accomplish expensive and time-consuming tests. Furthermore, in addition to weather forecast, mathematical models may be used in order to predict what may happen to stored grains (Corrêa et al., 2016).

Kachru \& Matthes (1976) studied the sorption pattern of rough rice, at temperatures between $19{ }^{\circ} \mathrm{C}$ and $42{ }^{\circ} \mathrm{C}$, demonstrating the hysteresis effect. Durakova \& Menkov (2004) reported the moisture sorption characteristics of rice flour at three storage temperatures $\left(10,20\right.$ and $\left.30^{\circ} \mathrm{C}\right)$, using the Brunauer-Emmett-Teller (BET) equation. Investigation on sorption isotherms of rice oil powder was done using the Guggenheim-Anderson-de Boer (GAB) model (Ratchanee et al., 2015). Mousa et al. (2014) researched the sorption isotherms of rough rice MR219 variety at temperatures of $20,30,40$ and $50^{\circ} \mathrm{C}$. However, researches aiming to analyze the sorption process of paddy rice grain, cv. Urucuia are scarce or absent in scientific literature. Studies on hygroscopic equilibrium for different agricultural products and cultivars are essential, even when products are physically and chemically similar. Absence of hygroscopicity data for paddy rice grain led the industry to use data from paddy red rice, resulting in significant errors regarding equilibrium moisture content values.
Due to the lack of researches regarding paddy rice grain hygroscopy and the need to properly store these grains, this work aimed to determine the sorption isotherms of paddy rice grain, obtained by desorption and adsorption, at different temperature and air relative humidity conditions and analyzing the hysteresis phenomenon.

\section{MATERIAL AND METHODS}

The study was conducted in the Agricultural Products Physical Properties and Quality Laboratory belonging to the National Storage Training Center (CENTREINAR), located at the Federal University of Viçosa, Viçosa, MG, Brazil.

Irrigated paddy rice grains $\mathrm{cv}$. Urucuia, from the EPAMIG Experimental Farm, in southern Minas Gerais, were used. Grains were hand harvested with an initial moisture content of approximately 0.28 (d.b.) and used in the desorption process. For the adsorption process, grains were dehydrated in an oven with forced air circulation (model $400-3 \mathrm{ND} /$ Gehaka brand) at $40^{\circ} \mathrm{C}$, until reaching a final moisture content of 0.17 (d.b.). Later, these grains were submitted to different air conditions in order to gain moisture (adsorption).

The static method (Brasil, 2009), with five different temperatures $\left(10,20,30,40\right.$ and $\left.50 \pm 1{ }^{\circ} \mathrm{C}\right)$ and four relative humidities $(10,30,50,70 \% \pm 2 \%$ ) (Table 1 ), was employed in order to acquire the equilibrium moisture content of paddy rice grains, for both desorption and adsorption processes. Thus, leading to a total of 20 different applied combinations.

TABLE 1 . Relative humidity values related to saturated salt solutions at temperatures of $10,20,30,40$ and $50^{\circ} \mathrm{C}$.

\begin{tabular}{cccccc}
\hline \multirow{2}{*}{ Saline solution } & \multicolumn{5}{c}{ Temperature $\left({ }^{\circ} \mathrm{C}\right)$} \\
\cline { 2 - 6 } & 10 & 20 & 30 & 40 & 50 \\
\hline $\mathrm{LiCl}$ & 11.3 & 11.3 & 11.3 & 11.2 & 11.1 \\
$\mathrm{MgCl}_{2}$ & 33.5 & 33.1 & 32.4 & 31.6 & 30.5 \\
$\mathrm{Mg}\left(\mathrm{NO}_{3}\right)_{2}$ & 57.4 & 54.4 & 51.4 & 49.9 & 45.4 \\
$\mathrm{NaCl}$ & 75.7 & 75.5 & 75.1 & 74.7 & 74.4 \\
\hline
\end{tabular}

Each saturated salt solution was placed inside hermetic desiccators. The sorption recipients were placed above the solutions, with three repetitions, containing approximately $20 \mathrm{~g}$ of sample. Desiccators containing the samples were placed in BOD chambers (model 347 $\mathrm{CD} /$ Fanem brand) in order to control the internal temperature required for the experiment.

During the process, sorption recipients were periodically (intervals of $24 \mathrm{~h}$ ) weighted in an analytical scale (model AY220/ Marte brand). Hygroscopic equilibrium was reached when mass variation remained invariable or lower than $0.01 \mathrm{~g}$ for three consecutive weighings. After hygroscopic equilibrium was reached, moisture content of each sample was determined using the gravimetric method, using an oven with forced air circulation at $105 \pm 1{ }^{\circ} \mathrm{C}$ for $24 \mathrm{~h}$ in three repetitions, according to Brasil (2009).

Sorption isotherms of paddy rice grain was determined using a mathematical model that best represented experimental data. This mathematical model was selected among the ones showed in Table 2, which are frequently used to represent the hygroscopicity of agricultural products. 
TABLE 2. Mathematical models to represent hygroscopic equilibrium curves.

\begin{tabular}{cc}
\hline Model name & Model \\
\hline Modified Henderson & $\mathrm{U}_{\mathrm{e}}=\left[\frac{\left.\ln \left(1-\mathrm{a}_{\mathrm{w}}\right)\right]^{\frac{1}{\mathrm{c}}}}{-\mathrm{a}(\mathrm{T}+\mathrm{b})}\right]^{\frac{1}{\mathrm{c}}}$ \\
\hline Modified Halsey & $\mathrm{U}_{\mathrm{e}}=\left[\frac{\exp (\mathrm{a}-\mathrm{bT})}{-\ln \left(\mathrm{a}_{\mathrm{w}}\right)}\right]^{\frac{\mathrm{c}}{2}}$ \\
\hline Modified Oswin & $\mathrm{U}_{\mathrm{e}}=(\mathrm{a}+\mathrm{bT})\left[\frac{\mathrm{a}_{\mathrm{w}}}{1-\mathrm{a}_{\mathrm{w}}}\right]^{\frac{1}{\mathrm{c}}}$ \\
\hline Copace & $\mathrm{U}_{\mathrm{e}}=\exp \left[\mathrm{a}-(\mathrm{bT})+\left(\mathrm{ca} \mathrm{a}_{\mathrm{w}}\right)\right]$ \\
\hline Sigma-Copace & $\mathrm{U}_{\mathrm{e}}=\exp \left[\mathrm{a}-(\mathrm{bT})+\mathrm{c} \exp \left(\mathrm{a}_{\mathrm{w}}\right)\right]$ \\
\hline Chung Pfost & $\mathrm{U}_{\mathrm{e}}=\mathrm{a}-\mathrm{b} \ln \left[-(\mathrm{T}+\mathrm{c}) \ln \left(\mathrm{a}_{\mathrm{w}}\right)\right]$ \\
\hline Smith & $\mathrm{U}_{\mathrm{e}}=\mathrm{a}-(\mathrm{bT})-\mathrm{cln}\left(1-\mathrm{a}_{\mathrm{w}}\right)$ \\
\hline Harkins Jura & $\mathrm{U}_{\mathrm{e}}=\frac{\exp (\mathrm{a}-\mathrm{bT})}{\mathrm{c}-\ln \left(\mathrm{a}_{\mathrm{w}}\right)}$ \\
\hline
\end{tabular}

In which:

$\mathrm{U}_{\mathrm{e}}$ - equilibrium moisture content, \% d.b.;

$\mathrm{a}_{\mathrm{w}}$ - water activity, (decimal);

$\mathrm{T}$ - temperature, $\left({ }^{\circ} \mathrm{C}\right)$, and

a, b, c - coefficients that depends upon the product.

Model was adjusted to experimental data by nonlinear regression analysis, throughout the Gauss-Newton method, using Statistica software. In order to select the model that best predicted the equilibrium moisture content of paddy rice grain, the following statistical parameters were considered: determination coefficient $\left(\mathrm{R}^{2}\right)$, mean relative error (MRE), estimated standard error (SEE), and randomness of residual values. The MRE and SEE values of each model were calculated using eqs (9) and (10), respectively:

$$
\begin{gathered}
M R E=\frac{100}{n} \sum \frac{|Y-\hat{Y}|}{Y} \\
S E E=\sqrt{\frac{\sum(Y-\hat{Y})^{2}}{D F}}
\end{gathered}
$$

In which:

MRE - mean relative error, $\%$;

SEE- estimate standard error, \% d.b.;

Y - observed value;

$\hat{\mathrm{Y}}$ - estimated value by the model;

$\mathrm{n}$ - number of observed data, and

DF - residual degrees of freedom (number of observed data minus number of model parameters).

Folowing model selection, analysis of the hysteresis phenomena was made using the sorption isotherms, which were obtained through the difference between the equilibrium moisture content values encountered for desorption and adsorption.

\section{RESULTS AND DISCUSSION}

Tables 3 and 4 show the parameters of the mathematical models fitted to the hygroscopic equilibrium experimental data, obtained for desorption and adsorption, respectively, under different air temperatures and relative humidities. Furthermore, values of mean relative error (MRE), estimated standard error (SEE), coefficient of determination $\left(\mathrm{R}^{2}\right)$ and residual values analysis are also presented. 
TABLE 3. Model parameters fitted to equilibrium moisture content of paddy rice grains, with coefficient of determination $\left(\mathrm{R}^{2}\right)$, estimated standard error (SEE) and mean relative error (MRE), obtained by desorption.

\begin{tabular}{|c|c|c|c|c|c|}
\hline Model & Parameters* & $\begin{array}{l}\mathrm{R}^{2} \\
(\%) \\
\end{array}$ & SEE (decimal) & $\begin{array}{c}\text { MRE } \\
(\%)\end{array}$ & Residual plot \\
\hline Modified Henderson & $\begin{array}{l}a=0.00005 \\
b=59.29579 \\
c=2.01760\end{array}$ & 99.08 & 0.74 & 8.07 & Random \\
\hline Modified Halsey & $\begin{array}{l}\mathrm{a}=4.978758 \\
\mathrm{~b}=0.011060 \\
\mathrm{c}=2.044422\end{array}$ & 97.43 & 1.19 & 13.65 & Biased \\
\hline Modified Oswin & $\begin{array}{l}a=14.25468 \\
b=-0.06960 \\
c=2.84464\end{array}$ & 98.80 & 0.84 & 8.89 & Biased \\
\hline Copace & $\begin{array}{l}a=1.839119 \\
b=0.005876 \\
c=1.639578\end{array}$ & 98.14 & 1.04 & 11.45 & Biased \\
\hline Sigma-Copace & $\begin{array}{l}a=1.032387 \\
b=0.005735 \\
c=0.959289\end{array}$ & 96.86 & 1.35 & 15.65 & Biased \\
\hline Chung Pfost & $\begin{array}{l}\mathrm{a}=37.41332 \\
\mathrm{~b}=6.23300 \\
\mathrm{c}=49.64200\end{array}$ & 99.60 & 0.49 & 5.16 & Random \\
\hline Smith & $\begin{array}{l}a=7.669984 \\
b=0.080895 \\
c=9.388660\end{array}$ & 98.34 & 0.99 & 11,45 & Biased \\
\hline Harkins-Jura & $\begin{array}{l}a=2.965899 \\
b=0.005945 \\
c=0.620576\end{array}$ & 98.92 & 0.80 & 8.69 & Random \\
\hline
\end{tabular}

* Significance level of $1 \%$ for " $t$ " test

TABLE 4. Model parameters fitted to equilibrium moisture content of paddy rice grains, with coefficient of determination $\left(\mathrm{R}^{2}\right)$, estimated standard error (SEE) and mean relative error (MRE), obtained by adsorption.

\begin{tabular}{|c|c|c|c|c|c|}
\hline Model & Parameters* & $\begin{array}{l}\mathrm{R}^{2} \\
(\%) \\
\end{array}$ & SEE (decimal) & $\begin{array}{c}\text { MRE } \\
(\%)\end{array}$ & Residual plot \\
\hline Modified Henderson & $\begin{array}{l}\mathrm{a}=0.00008 \\
\mathrm{~b}=62.29053 \\
\mathrm{c}=1.87538\end{array}$ & 99.11 & 0.70 & 9.59 & Random \\
\hline Modified Halsey & $\begin{array}{l}\mathrm{a}=4.478713 \\
\mathrm{~b}=0.010657 \\
\mathrm{c}=1.915281\end{array}$ & 97.81 & 1.11 & 14.78 & Biased \\
\hline Modified Oswin & $\begin{array}{l}a=13.11786 \\
b=-0.06562 \\
c=2.65584\end{array}$ & 98.96 & 0.76 & 9.88 & Random \\
\hline Copace & $\begin{array}{l}\mathrm{a}=1.700181 \\
\mathrm{~b}=0.006091 \\
\mathrm{c}=1.754145\end{array}$ & 98.45 & 0.93 & 12.22 & Random \\
\hline Sigma-Copace & $\begin{array}{l}\mathrm{a}=0.841173 \\
\mathrm{~b}=0.005930 \\
\mathrm{c}=1.024176\end{array}$ & 97.35 & 1.21 & 16.84 & Biased \\
\hline Chung Pfost & $\begin{array}{l}a=35.93673 \\
b=6.08728 \\
c=50.48329\end{array}$ & 99.64 & 0.45 & 5.99 & Random \\
\hline Smith & $\begin{array}{l}a=6.747202 \\
b=0.077581 \\
c=9.217345\end{array}$ & 98.80 & 0.82 & 11.25 & Biased \\
\hline Harkins-Jura & $\begin{array}{l}\mathrm{a}=2.809354 \\
\mathrm{~b}=0.006131 \\
\mathrm{c}=0.531248\end{array}$ & 99.02 & 0.74 & 9.82 & Random \\
\hline
\end{tabular}

* Significant at $1 \%$ probability by " $\mathrm{t}$ " test 
The analyzes of tables 3 and 4 , show that all mathematical models had elevated coefficient of determination values, which according to Kashaninejad et al. (2007) indicates a satisfactory representation of this models to the phenomenon under investigation. However, the coefficient of determination must be used just as an aid index for nonlinear models (Baptestini et al., 2017a). For a more detailed analysis, remaining statistical parameters must be used.

Several authors argue that a model is adequate if the MRE value is lower than 10\% (Rosa et al., 2010; CastellPalou et al., 2012; Corrêa et al., 2014; Costa et al., 2015). According to Kashaninejad et al. (2007), MRE values indicates a deviation of the observed values, relating to the estimated curve by the model. Thus, it was verified that Modified Henderson, Modified Oswin, Chung Pfost and Harkins-Jura models had satisfactory MRE values (below $10 \%$ ). However, among the listed models, the Chung Pfost model had the lower MRE values, in both sorption processes.

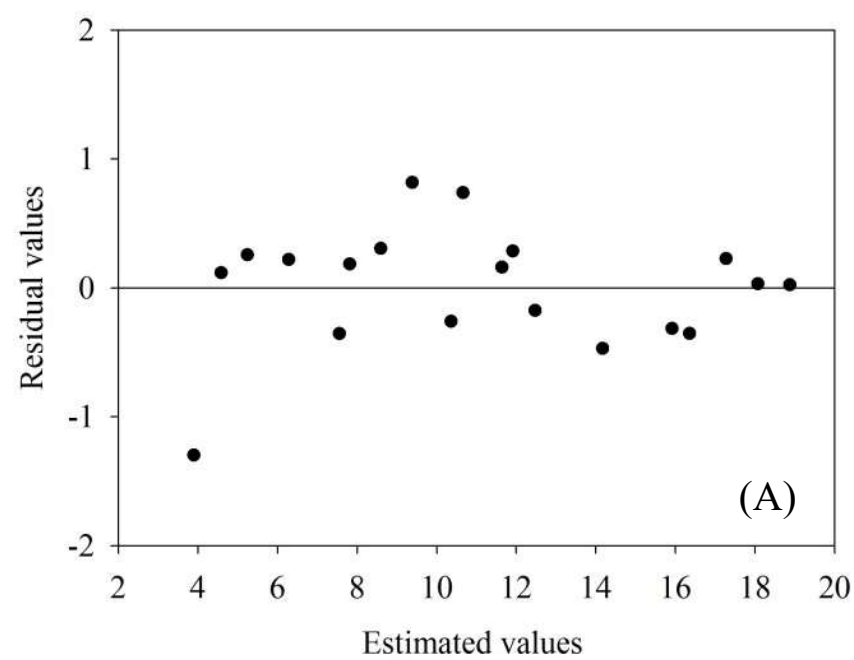

According to Draper \& Smith (1998), the model's ability to reliably describe a specific physical process is inversely proportional to the SEE value. Thus, lower values of this variable indicate a better fit of the model to the observed data. Chung Pfost model also had lower SEE values among the tested models.

To assure that the selected model is capable to describe the phenomenon, an analysis of the residual plot is recommended. The chosen model must have residual values close to the horizontal zone, around zero, and should not form geometric figures. If these trends occur, the model will have regions that overestimate or underestimate the real condition, thus the model is inadequate to represent the phenomenon under study (Goneli et al., 2011; Alves et al., 2013; Corrêa et al., 2014).

Residual distribution in the Chung Pfost model, for both desorption and adsorption, is random among the equilibrium moisture content range, with positive and negative values (Figure 1).

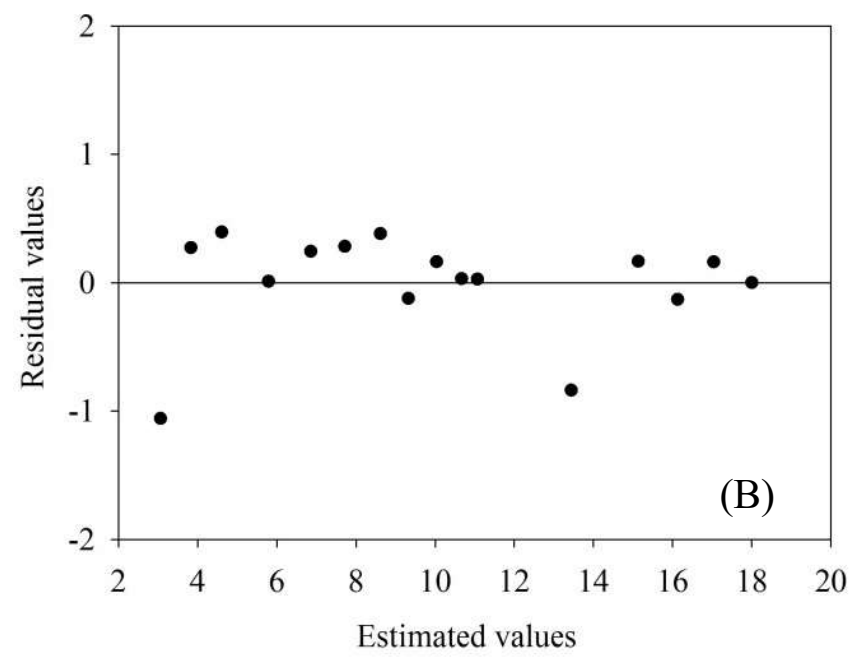

FIGURE 1. Chung Pfost model residual values for desorption (A) and adsorption (B) of paddy rice grains.

Through analyses of the statistical parameters used in this study, it be concluded that the Chung Pfost model was the most representative of hygroscopic equilibrium for the paddy rice grain experimental data, showing $\mathrm{R}^{2}$ between 99.60 and $99.64 \%$, SEE between 0.49 and 0.45 and MRE between 5.16 and $5.99 \%$, along with residual random distribution. Mousa et al. (2014) recommended the Oswin model to represent sorption of Malaysian paddy, indicating the importance of studying different varieties of the same product, due to differences in chemical composition.

According to Ullmann et al. (2016), the Chung Pfost model has been used for starchy products, being the model chosen to represent the hygroscopicity of sweet sorghum seeds. This model also fitted satisfactorily to hygroscopic equilibrium of okra (Goneli et al., 2010), wheat (Li, 2012), cotton (Oliveira et al., 2013), sugar beet (Corrêa et al., 2016), kalibu chickpea, black sesame and white sesame(Armstrong et al., 2017) and red kidney beans (Jian \& Jayas, 2018) seeds.

Figure 2 shows the experimental results of equilibrium moisture content of paddy rice grain, obtained for desorption and adsorption, along with the isotherms determined by the Chung Pfost model. 

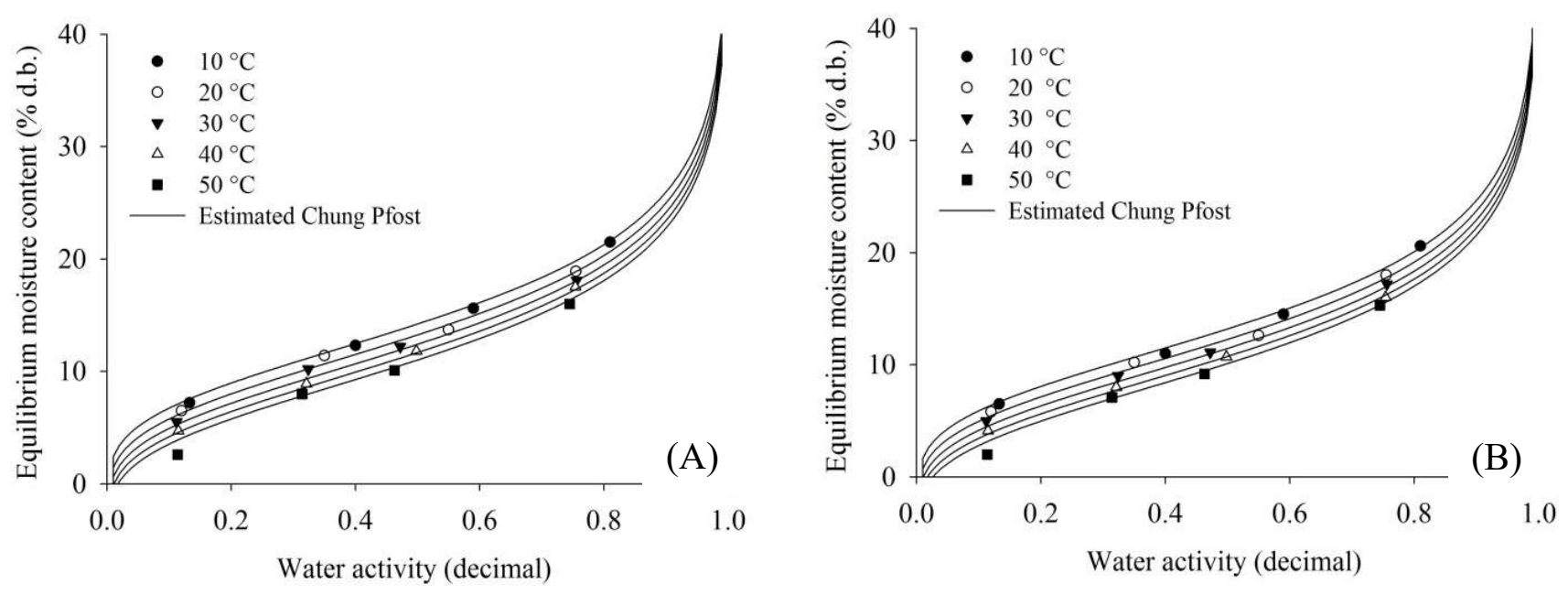

FIGURE 2. Observed and estimated values, by the Chung Pfost model, of equilibrium moisture content of paddy rice grain, obtained for desorption (A) and adsorption (B).

Through Figure 2, it can be verified temperature influence over the sorption isotherms of paddy rice grain, since it requires an increment of water activity in order to attain the same equilibrium moisture content for increasing temperature. Recent studies reported the same behavior for different agricultural products (Oliveira et al., 2017a; Oliveira et al., 2017b; Zeymer et al., 2017; Arufe et al., 2018; Espinosa-Andrews \& Rodríguez-Rodríguez, 2018).

García-Pérez et al. (2008) argue that as temperature rises, there is an increase of the molecular disorder degree of water present at the adsorbent surface, leading to instability and facilitating the breakage of intermolecular connections between water molecules and sorption sites, thus allowing water vaporization and, consequently, decreasing equilibrium moisture content.

Desorption and adsorption isotherms of paddy rice grain (Figure 2) exhibited a sigmoidal shape type, characteristic of a type II curve, according to the IUPAC classification (1985). As stated by Labuza \& Altunakar
(2007), the type II isotherms shape is caused by synergistic effects of the Raoult's law, capillaries effects and moisture interactions at the material surface.. These authors also report that this isotherm shape describes two regions, one between 0.2 and 0.4 of equilibrium moisture content and another between 0.6 and 0.7 . These regions are the result of physicochemical processes, such as, the multilayers creation and the pores filling (0.2-0.4 region), followed by larger pores filling and solutes dissolution (0.6-0.7 region). Several researchers verified the same pattern in starchy products, including rice (Brett et al., 2009; Mousa et al., 2014; Chen et al., 2017; Purohit \& Rao, 2017; Zhao et al., 2017).

Table 5 shows temperature and relative humidity values used in the experiment, along with the equilibrium moisture content for paddy rice grains experimental data obtained for desorption and adsorption, and hysteresis magnitudes.

TABLE 5. Equilibrium moisture content experimental values for desorption, adsorption and hysteresis of paddy rice grains.

\begin{tabular}{|c|c|c|c|c|}
\hline Temperature $\left({ }^{\circ} \mathrm{C}\right)$ & Relative humidity (\%) & $\begin{array}{c}\mathrm{U}_{\mathrm{e}} \text { desorption } \\
(\% \text { d.b.) }\end{array}$ & $\begin{array}{c}\mathrm{U}_{\mathrm{e}} \text { adsorption } \\
(\% \text { d.b.) }\end{array}$ & $\begin{array}{c}\text { Hysteresis } \\
\text { (\% d.b.) }\end{array}$ \\
\hline \multirow{4}{*}{10} & 13.30 & 7.20 & 6.50 & 0.700 \\
\hline & 40.00 & 12.30 & 11.00 & 1.300 \\
\hline & 59.00 & 15.60 & 14.50 & 1.100 \\
\hline & 81.00 & 21.50 & 20.60 & 0.900 \\
\hline \multirow{4}{*}{20} & 12.00 & 6.50 & 5.80 & 0.700 \\
\hline & 35.00 & 11.40 & 10.20 & 1.200 \\
\hline & 55.00 & 13.70 & 12.60 & 1.100 \\
\hline & 75.50 & 18.90 & 18.00 & 0.900 \\
\hline \multirow{4}{*}{30} & 11.20 & 5.50 & 5.00 & 0.500 \\
\hline & 32.40 & 10.20 & 9.00 & 1.200 \\
\hline & 47.20 & 12.20 & 11.10 & 1.100 \\
\hline & 75.60 & 18.10 & 17.20 & 0.900 \\
\hline \multirow{4}{*}{40} & 11.50 & 4.70 & 4.10 & 0.600 \\
\hline & 32.10 & 8.90 & 8.00 & 0.900 \\
\hline & 49.80 & 11.80 & 10.70 & 1.100 \\
\hline & 75.40 & 17.50 & 16.60 & 0.900 \\
\hline \multirow{4}{*}{50} & 11.40 & 2.60 & 2.00 & 0.600 \\
\hline & 31.40 & 8.00 & 7.10 & 0.900 \\
\hline & 46.30 & 10.10 & 9.20 & 0.900 \\
\hline & 74.50 & 16.00 & 15.30 & 0.700 \\
\hline
\end{tabular}


in which,

$\mathrm{U}_{\mathrm{e}}$ desorption - equilibrium moisture content of desorption, \% d.b.,

$\mathrm{U}_{\mathrm{e}}$ adsorption - equilibrium moisture content of adsorption, \% d.b.

Comparing equilibrium moisture content values for desorption and adsorption, for all air conditions used, leads to the conclusion that values acquired for desorption are always higher than those obtained for adsorption (Table 5).

One of the most accepted theories to explain the hysteresis phenomenon suggests that, during adsorption, the grain porous region formed by capillaries begins to swell up, due to the increase in relative humidity. When partial pressure of the the air's water vapor becomes higher than the capillary's vapor pressure, water moves towards the pore interior. During desorption, the pore is saturated at the beginning of the process. Water diffusion, from the grain's periphery to surface, occurs when the partial pressure of the surrounding air's water vapor is lower than the vapor pressure inside the capillary (Lahsasni et al., 2004).

It is possible to observe the temperature and water activity effect at the hysteresis (equilibrium moisture content of desorption minus the equilibrium moisture content of adsorption) of paddy rice grain in Figure 3.

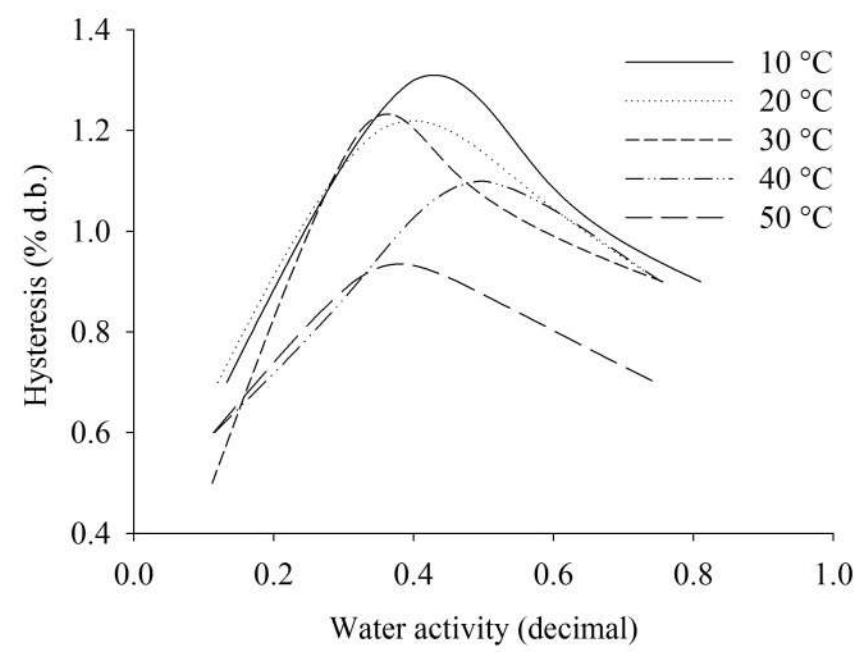

FIGURE 3. Temperature effect and water activity on hysteresis variation of paddy rice grains.

Hysteresis effect occurs during the entire water activity range, being more pronounced between 0.32 and 0.59 , for all temperatures evaluated (Figure 3).

Analyzes of Figure 3, shows that hysteresis magnitudes decrease as temperature increases, as verified by different authors (Bejar et al., 2012; Corrêa et al., 2014; Souza et al., 2015; Goneli et al., 2016; Baptestini et al., 2017b; Torres et al., 2018). However, hysteresis values at $30{ }^{\circ} \mathrm{C}$ were higher than hysteresis at $20{ }^{\circ} \mathrm{C}$, at the water activity interval between 0.3 and 0.4 , probably due to the elasticity increase of the capillary walls. Similar results were encountered by Dalgiç et al., (2012), studying sorption isotherms and thermodynamic properties of mint leaves at temperatures of 15,25 and $35^{\circ} \mathrm{C}$. These authors verified that the hysteresis value at $25^{\circ} \mathrm{C}$ was lower when compared to the hysteresis at $35^{\circ} \mathrm{C}$.

\section{CONCLUSIONS}

Equilibrium moisture content of paddy rice grain cv. Urucuia, is directly proportional to relative humidity and decreases as temperature increases, at a constant value of water activity.

Based on statistical parameters, the Chung Pfost model was the one that best fitted to experimental data, when compared to the other tested models, thus being chosen to represent the hygroscopicity of paddy rice grain.
Desorption and adsorption isotherms of paddy rice grain cv. Urucuia, represented by Chung Pfost model, exhibited a sigmoidal shape, characteristic of a type II curve.

Equilibrium moisture content values were higher for desorption than for adsorption, indicating the hysteresis phenomenon.

\section{ACKNOWLEDGEMENTS}

The authors would like to thank the Coordenação de Aperfeiçoamento Pessoal de Nivel Superior - CAPES (Coordination for the Improvement of Higher Education Personnel) for the essential support and financial aid in the form of Master's degree scholarship.

\section{REFERENCES}

Alves GE, Isquierdo EP, Borém FM, Siqueira VC, Oliveira PD, Andrade ET (2013) Cinética de secagem de café natural para diferentes temperaturas e baixa umidade relativa. Coffee Science 8(2):238-247.

Armstrong PR, Maghirang EB, Bhadriraju S, McNeill SG (2017) Equilibrium moisture content of kalibu chickpea, black sesame, and white sesame seeds. American Society of Agricultural and Biological Engineers 33(5):737-742.

Arufe S, Torres MD, Chenlo F, Moreira R (2018) Air drying modeling of Mastocarpus stellatus seaweed a source of hybrid carrageenan. Heat and Mass Transfer 54(1):177-184. 
Baptestini FM, Corrêa PC, Oliveira GHH, Cecon PR, Soares NFF (2017a) Kinetic modeling of water sorption by roasted and ground coffee. Acta Scientiarum 39(3):273-281.

Baptestini FM, Corrêa PC, Vanegas JDB, Leite R, Botelho FM, Campos RC (2017b) Water sorption kinetics of damage beans: GAB model. Revista Brasileira de Engenharia Agrícola e Ambiental 21(8):556-561.

Bejar AK, Boudhrioua NM, Kechaou N (2012) Moisture sorption isotherms - Experimental and mathematical investigations of orange (Citrus sinensis) peel and leaves. Journal Food Chemistry 32(4):1728-1735.

Brasil (2009) Ministério da Agricultura e Reforma Agrária. Regras para análises de sementes. Brasília, Secretaria Nacional de Defesa Agropecuária. 399p.

Brett B, Figueroa M, Sandoval A, Barreiro J, Muller A (2009) Moisture sorption characteristics of starchy products: oat flour and rice flour. Food Biophysics 4(3):151-157.

Brooker DB, Bakker-Arkema FW, Hall CW (1992) Drying and storage of grains and oil seeds. Westport: The AVI Publishing Company, 450p.

Castell-Palou A, Váquiro HÁ, Cárcel JA, Rosselló C, Femenia A, Simal S (2012) Mathematical modeling of moisture distribution and kinetics in cheese drying. Drying Technology 30(11-12):1247-1255.

Chen H, Hong G, Chen Z (2017) Moisture sorption isotherms characteristics and Taguchi analysis of rice bran extraction parameters. Asia-Pacific of Chemical Engineering 12(1):33-41.

Chen Y, Jiang W, Jiang Z, Chen X, Cao J, Dong W, Dai B (2015) Changes in physicochemical, structural and sensory properties of irradiated brown japonica rice during storage. Journal of Agriculture and Food Chemistry 63(17):4361-4369.

Corrêa PC, Botelho FM, Botelho SCC, Goneli ALD (2014) Isotermas de sorção de água de frutos de Coffea canephora. Revista Brasileira de Engenharia Agrícola e Ambiental 18(10):1047-1052.

Corrêa PC, Oliveira GHH, Botelho FM, Goneli ALD, Carvalho FM (2010) Modelagem matemática e determinação das propriedades termodinâmicas do café (Coffea arábica L.) durante o processo de secagem. Revista Ceres 57(5):595-601.

Corrêa PC, Oliveira GHH, Oliveira APLR, Goneli ALD, Botelho FM (2016) Isotermas de dessorção de sementes de beterraba. Engenharia na Agricultura 24(1):15-21.

Costa JMG, Silva EK, Hijo AACT, Azevedo VM, Borges SV (2015) Physical and thermal stability of spray-dried swiss cheese bioaroma powder. Drying Technology 33(3):346-354.

Dalgiç AC, Pekmez H, Belibagli KB (2012) Effect of drying methods on the moisture sorption isotherms and thermodynamic properties of mint leaves. Journal of Food Science Technology 49(4):439-449.

Draper NR, Smith H (1998) Applied regression analysis. New York: John Wiley \& Sons, 3 ed. 712p.
Durakova AG, Menkov ND (2004) Moisture sorption characteristics of rice flour. Nahrung/Food, 48(2):137-140.

Espinosa-Andrews H, Rodríguez-Rodríguez R (2018) Water state diagram and thermal properties of fructans powders. Journal of Thermal Analysis and Calorimetry 132(1):197-204.

Fellows JP (2006) Tecnologia do processamento de Alimentos: princípios e prática. Porto Alegre, Artmed, 2 ed. $602 \mathrm{p}$.

García-Pérez JV, Cárcel JA, Clemente G, Mulet A (2008) Water sorption isotherms for lemon peel at different temperatures and isosteric heats. LTW - Food Science and Technology 41(1):18-25.

Goneli ALD, Corrêa PC, Magalhães, FEA, Baptestini, FM (2011) Contração volumétrica e forma dos frutos de mamona durante a secagem. Acta Scientiarum Agronomy 33(1):1-8.

Goneli ALD, Corrêa PC, Oliveira GHH, Botelho FM (2010) Water desorption and thermodynamic properties of okra seeds. Transactions of the ASABE 53(1):191-197.

Goneli ALD, Corrêa PC, Oliveira GHH, Resende O, Mauad M (2016) Moisture sorption isotherms of castor beans. Part 1: Mathematical modeling and hysteresis. Revista Brasileira de Engenharia Agrícola e Ambiental 20(8):751-756.

IUPAC - International Union of Pure and Applied Chemistry (1985) Reporting Physisorption data for gas/solid systems with special reference to the determination of surface area and porosity. Pure \& Applied Chemistry 57(4):603-619.

Jian F, Jayas D (2018) Characterization of isotherms and thin-layer drying of red kidney beans, part I, choosing appropriate empirical and semitheoretical models. Drying Technology:1-11.

Kachru RP, Matthes RK (1976) The behavior of rough rice in sorption. Journal of Agricultural Engineering Research 21:405-416.

Kashaninejad M, Mortazavi A, Safekordi A, Tabil LG (2007) Thin-layer drying characteristics and modeling of pistachio nuts. Journal of Food Engineering 78(1):98-108.

Labuza TP, Altunakar B (2007) Water Activity Prediction and Moisture Sorption Isotherms. In: Barbosa-Cánovas GV, Fontana JR AJ, Schmidt SJ, Labuza TP (eds). Water activity in foods: fundamentals and applications. Ames, Blackwell Publishing Professional, p109-154.

Lahsasni S, Kouhila M, Mahrouz M (2004) Adsorptiondesorption isotherms and heat of sorption of prickly pear fruit (Opuntia ficus indica). Energy Conversion and Management 45(2):249-261.

Li X (2012) The hygroscopic properties and sorption isosteric heats of different chinese wheat types. Journal of Food Research 1(2):82-98.

Mousa W, Ghazali FM, Jinap S, Ghazali HM, Radu S (2014) Sorption isotherms and isosteric heats of sorption of Malaysian paddy. Journal of Food Science and Technology 51(10):2656-2663. 
Oliveira GHH, Corrêa PC, Oliveira APRL, Baptestini FM, Vargas-Elías GA (2017a) Roasting, grinding, and storage impact on thermodynamic properties and adsorption isotherms of arabica coffee. Journal of Food Processing and Preservation 41(2). DOI:

https://doi.org/10.1111/jfpp.12779

Oliveira GHH, Corrêa PC, Oliveira APRL, Reis RC, Devilla IA (2017b) Application of GAB model for water desorption isotherms and thermodynamic analysis of sugar beet seeds. Journal of Food Process Engineering 40(1).

Oliveira DEC, Resende O, Smaniotto TAS, Campos RC (2013) Isotermas e calor isostérico das sementes de algodão com línter e sem línter. Revista Brasileira de Produtos Agroindustriais 15(3): 283-292.

Purohit SR, Rao PS (2017) Modelling and analysis of moisture sorption isotherm of raw and pregelatinized rice flour and its crystalline status prediction. Food Analytical Methods 10(6):1914-1921.

Ratchanee C, Anuvat J, Kamolwan J, Thepkunya H, Julian MD (2015) The Physical Characterization and Sorption Isotherm of Rice Bran Oil Powders Stabilized by FoodGrade Biopolymers. Drying Technology 33(4):479-492.

Rosa GS, Moraes MA, Pinto LAA (2010) Moisture sorption properties of chitosan. Lebensmittel-Wissenschaft und - Technologie 43(3):415-420.

Souza SJF, Alves AI, Vieira ENR, Vieira JAG, Ramos AM, Telis-Romero J (2015) Study of thermodynamic water properties and moisture sorption hysteresis of mango skin. Food Science and Technology 35(1):157-166.
Torres MD, Chenlo F, Moreira, R (2018) Structural features and water sorption isotherms of carrageenans: A prediction model for hybrid carrageenans. Carbohydrate Polymers 180:72-80.

Ullmann R, Resende O, Oliveira DEC, Costa LM, Chaves TH (2016) Higroscopicidade das sementes de sorgosacarino. Revista Engenharia Agrícola 36(3):515-524.

Utami S, Widyastuti U, Utami DW, Rosdianti I, Lestari P (2017) Molecular marker-assisted selection of rice grain quality on rice (Oryza sativa L.) lines tolerant to fe toxicity stress. The Journal of Tropical Life Science 7(3):268-276.

Zeymer JS, Corrêa PC, Oliveira GHH, Baptestini FM, Freitas RCP (2017) Desorption isotherms of lactuca sativa seeds. Revista Brasileira de Engenharia Agrícola e Ambiental 21(8):568-572.

Zhao X, Zhang H, Duan R, Feng Z (2017) The states of water in glutinuous rice flour characterized by interpreting desorption isotherm. Journal of Food Science and Technology 54(6):1491-1501.

Ziegler W, Ferreira CD, Tonieto L, Silva JGS, Oliveira M, Elías MC (2017) Efeitos da temperatura de armazenamento de grãos de arroz integral de pericarpo pardo, preto e vermelho sobre as propriedades físicoquímicas e de pasta. Brazilian Journal of Food Technology 20:e2016051.

Wolf M, Walker JE, Kapsalis JG (1972) Water sorption hysteresis in dehydrated food. Journal of Agricultural and Food Chemistry 20(5):1073-1077. 